\title{
Health and Socio Economic Status of Tobacco Workers in Malawi
}

\author{
G. Thiruvasagam, D. Rajasekar, R. Vettriselvan
}

\begin{abstract}
Tobacco is the major money crop of Malawi and it contributed the maximum of the national income. Malawi is the major contributor in the tobacco production of the world and many of the cigarette companies are using the burley leaf tobacco produced in the Malawian farm due to its rich taste and quality. Tobacco is a major smoking device used by millions of people all over the Malawi who can't afford the pleasure of smoking a cigarette because of the price that is prohibitive taking in to consideration the economic status of the majority of smokers all over the nation. Smoking tobacco suited the financial strength of the emerging industries workers and agricultural labourers. In this study made an attempt to study the health and socioeconomic aspects of the tobacco workers, to find out the nature of work conditions of the tobacco workers, to study the awareness of tobacco workers with regard to family problems and to find out their participation in religious gathering. This study found that tobacco workers were lives in most of the rural areas of Malawi through secondary data pertained from the Government and Non Government sources. Population method was adopted to collect the information from the tobacco workers in the study area. This study found that Tobacco is not only injurious to health of the smokers and also to the makers of the Tobacco (Tobacco workers) too. Socio-economic status of the tobacco worker also very poor when compare with the minimum wages in the study area. These tobacco workers are forced to engage this sector due to non availability of other kind of jobs and lack of skills to engage in the other jobs. This study concludes that Government and Non Governmental organizations should take necessary actions to improve the health and socio economic status through providing vocational training and guidance to enhance their skills and help them in self employment opportunities. Further, it opens up new avenues for the future researchers to contribute more on this to enhance the health condition from all the parts of the world.
\end{abstract}

Index Terms: Tobacco Workers, Health, Socio Economic, employment, malnutrition

\section{INTRODUCTION}

Tobacco is a cheap smoking device used by thousands of rural and poor people all over the world, but in Malawi who can't afford the pleasure of drinking liqor because of the price that is prohibitive taking in to consideration the economic status of the majority of smokers all over the nation. Smoking tobacco suited the financial strength of the emerging industries workers and agricultural workers. Smoking tobacco is the sign of poor, casual and unskilled worker in the society. Many of the smokers used tobacco due to the lack of economic freedom they are enjoying the society such as wage earners and manual workers who

\footnotetext{
Revised Manuscript Received on 14 August, 2019.

Col.Dr.G.Thiruvasagam, Vicechancellor, AMET Deemed to be University, Chennai, Tamilnadu, India

Dr.D.Rajasekar,Professor,m AMET Business School, AMET, Chennai, Tamilnadu, India.

Dr.R.Vettriselvan, Lecturer, School of Commerce and Management, DMI-St. John the Baptist University, Mangochi, Malawi.
}

doesn't bother about the odor of tobacco and health condition. Tobacco workers are the one of the marginalized working group in the society due to lower wages and poor demand for the tobacco in the local market. This marginalized group of people doesn't think about the hygiene and safety working environment and also their personal health. Tobacco workers are doesn't have the proper housing, proper education to their wards due to their economic status, lack of outside employment opportunities due to poor skill in other segment. Hence, this attempt is most important to study the health and socio economic status of tobacco workers in the study area to provide the possible solutions.

\section{TOBACCO WORKERS IN MALAWI}

Man uses various forms of economic organization in gaining livelihood. The basic purpose of every form is the same to satisfy as may of man's unlimited wants as can be satisfied from the source of production at his disposal the way man attempts to achieve this. Basic purpose differs in major respects from age to age and place. Tobacco workers use their profession from which they get inadequate income to meet their manifold needs. Tobacco farm workers constitute one of the weaker but most neglected sections of workers in the whole of Malawi. Even then they possess a numerical strength of remarkable production of quality tobacco are among the world famous industries in Malawi. Low wages insecurity of employment, partial employment, employment of children, high incidents of Tuberculosis, absences of productive labours legislation, had work and branch system demand to directive immediate legislative with a view for regulating the above industries as a factor basic and seeking the workers minimum condition of work.

\section{SOCIO-ECONOMIC AND HEALTH CONDITION}

The lives of tobacco workers are characterized by poverty indebtedness ill health, social stagnation etc. this mainly because the tobacco workers work long hours and are exposed to health hazards such Tuberculosis and nerve weakness notwithstanding the fact that they are prone to evils of drinking in order to relax their tired bodies and weary tired. The remuneration for their toil is minimal and this force those to resort to money lenders who change a very high rate of interest thus results in making their children were in order to augment the family income this causing them to end their education abruptly. In the ultimate analysis education levels are low and it impacts social

Published By:

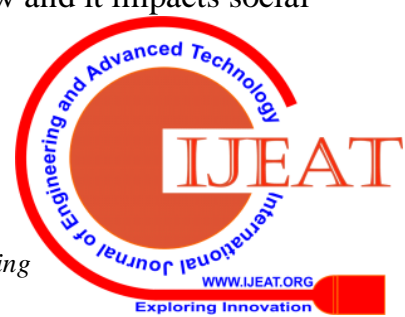


growth due to ignorance and exploitation arising art. It is a vicious circle and the tobacco workers seem to see no light at the end of the tunnel unless some drastic measures are taken to better then-lot, in order to the tobacco workers barely manage to exist as their conditions are pitiable and has remained this way for generation.

\section{STATEMENT OF THE PROBLEM}

The general condition of tobacco workers is very poor and despite the various welfare schemes and legislative that are passed to better life conditions. But, lot of tobacco workers related schemes much remains unimplemented. This study attempts to find out the conditions of life and work of the tobacco workers which are characterized by the low income long hours of work huge indebtedness, poor nutrition, unhygienic living condition and workers has remained unchanged. The progeny of the tobacco workers economic necessities and end up without education that them to tobacco workers do not live but barely service. This interested the researcher to study in detail the life and working condition of the tobacco workers.

\section{SCOPE AND SIGNIFICANCE OF THE STUDY}

It is prime objective that to study the various factors affecting conditions of tobacco workers. It is well known fact that problems of tobacco workers are identified, they are society backward and their economical status is also poor, due to their nature of work they get low income. Illiteracy and heredity play a vital role in determining their social economic condition because, they are ignorant and are not aware of the development programmes available for them. The nature occupation leads to the physical hazards like Asthma, and other heart related diseases. They are captured by social problem like alcohol; due to their drug addiction their body becomes weak so their life span also is getting decreased.

\section{OBJECTIVES OF THE STUDY}

To study the socio-demographic aspects of the tobacco workers;

To find out the nature of work conditions of the tobacco workers;

To study the awareness of tobacco workers with regard to family problems; and

$\square \quad$ To find out their participation in religious gathering.

\section{RESEARCH METHODOLOGY}

The design for the study is descriptive design. It is the design which describes the different characteristics of the theory formation only the facts and character were gathered also it presents the view regard to predict future trends which finds out the relationship between the variables. According to the study tobacco worker is a person engaged in the farming of tobacco and also processing the tobacco leaves and manufacture the raw materials for cigarette manufacturers, the person may be skilled in tobacco making and eligible to get benefit under different schemes being are found into this profession at a young age due to social phenomena under this there is no emphasis on the

implemented for tobacco wafer. The universe of the present study comprises of 450 tobacco farming and processing workers around Mangochi. The researcher selected 150 samples as a sample size of one third of the population. This study adopted stratified random sampling used to draw samples from the universe and the size of the sample is 150 respondents. The researcher used a structured self prepared interview schedule for collection of data. The interview schedule formulated by researcher is based on the aims and objectives of the study covering the aspects of social, economical and health condition of tobacco workers. The source of data was primary and it was obtained from the tobacco workers both men and women working at various tobacco farms in and around namely Monkey bay, Chitele, Bitchilipa and Chimwala. The researcher interviewed 150 respondents data were collected from the. Since the researcher had a face to face interaction with the respondent, the former was able to get a fairly good response from the later.

\section{Garrett's Ranking Technique for major problems}

This technique is used to understand the health and psychological issues faced by the women construction workers in the study area.

$100\left(\mathrm{R}_{\mathrm{ij}}-0.5\right)$

Percentage Position =

$\mathrm{Nj}$

$\mathrm{R}_{\mathrm{ij}}=$ Rank given for the $\mathrm{i}^{\text {th }}$ item or scheme by the $\mathrm{j}^{\text {th }}$ individual

$\mathrm{j}=$ Number of schemes ranked by the $\mathrm{j}^{\text {th }}$ individual

The percentage position of each rank related to the health and safety thus obtained was converted into scores by referring to the ranking table given by Garrett. The ranking was done according to the average score obtained for each problems. The ranks obtained from the tobacco workers about the existing problems were converted in to the scores by applying Garrett scoring technique and finally the average values of the obtained scores were ranked as follows.

Garrett's Ranking for the health and psychological issues of tobacco workers

\begin{tabular}{|c|l|l|l|l|}
\hline $\begin{array}{c}\text { S. } \\
\text { N } \\
\text { o. }\end{array}$ & Problem & $\begin{array}{l}\text { Total } \\
\text { Score }\end{array}$ & $\begin{array}{l}\text { Average } \\
\text { Score }\end{array}$ & $\begin{array}{l}\text { Ran } \\
\text { k }\end{array}$ \\
\hline 1. & $\begin{array}{l}\text { Inadequate salary to get } \\
\text { food material }\end{array}$ & 5601 & 37.34 & VI \\
\hline 2. & Poor safety measures & 6873 & 45.82 & V \\
\hline 3. & Sexual issues & 9711 & 64.74 & II \\
\hline 4. & Work life balance & 8671 & 57.81 & III \\
\hline 5. & $\begin{array}{l}\text { Lack of accommodation } \\
\text { facilities }\end{array}$ & 8134 & 54.23 & IV \\
\hline 6. & $\begin{array}{l}\text { Poor work life } \\
\text { environment }\end{array}$ & 4488 & 29.92 & VII \\
\hline 7. & $\begin{array}{l}\text { Nutritional deficit } \\
\text { Source Computed from field }\end{array}$ & 68.34 & I \\
\hline
\end{tabular}

Source: Computed from field data 
The results of the Garrett Ranking reveal the health and psychological issues of tobacco workers in Mangochi district. From the view of the workers nutritional deficit, sexual issues, poor work life balance (poor support from the family members), lack of accommodation facilities (not getting proper roof to live), poor safety measures (not able to get the first aid for any health issues), inadequate salary to buy food materials (not able to fulfill the needs of the self and family members) and poor work life environment (absence of rest room facilities, canteen and so on.. are the major issues faced by the tobacco workers of Mangochi district as per the response of the workers ranked respectively.

\section{FINDINGS OF THE STUDY}

More than Half (64 percent) of the respondents belong to the respondents of the age group of 35-40 years;

Average monthly salary of the respondents between MWK 18750 to MWK 27000 (25 to 35 USD);

$\square \quad$ Majority (72 percent) of the respondents are female;

More than Half (66 percent) of the respondents belong to the Muslims;

More than Half (52 percent) of the respondents were coming from rural/ remote places;

$\square \quad$ Nearly half (42 percent) of the respondents illiterate; joint family;

Majority (72 percent) of the respondents having the

Half (52 percent) of the respondents not married;

Less than ( 24 percent) half of the respondents are not having the proper house;

More than (64 percent) half of the respondents not availed any facilities;

Half (52 percent) of the respondents are not satisfied with the salary;

Less than one their (32 percent) of the respondents are expenditure in food;

More than Half (54 percent) of the respondents have not able to fulfill the need of the family by their earnings;

More than Half (68 percent) of the respondents the social gathering of their community;

Majority (72 percent) of the respondents getting the temporary job;

Half (52 percent) of the respondents are not satisfied in their job;

Half (58 percent) of the respondents practice of down, system;

Less than half (48 percent) of the respondents having below average health condition;

Vast Majority (78 percent) of the respondents are having the diseases on their job;

Majority (72 percent) of the respondents not associated with their employer;

About (26 percent) more than one forth of them having the tuberculosis;

More than half (53 percent) of the female workers were sexually abused by the co workers and superiors for job;
Mostly mbatata (sweet potato) is the food material used by all the tobacco workers and rarely they will use rice during any festival occasions; and

Due to their food habit most of these tobacco workers are comes under malnutrition category.

\section{SUGGESTIONS}

Steps should be taken to register the tobacco workers. So that they will enjoy the security of job;

Medical facilities should be improved in the community;

The salary should be increased compared to the global job market;

Orientation of the various welfare programmes should be given in order to erase the ignorance and sentiments attitude regarding different crucial issues;

Regular medical check-up could be organized by the government, primary health centre, and nongovernmental organisation for the tobacco workers, in order to overcome their occupational diseases;

It is suggested that Government may provide alternative job and permanent income sources for the tobacco workers; and

The tobacco manufacturers suppose to provide some basic accommodation facilities and healthy food material to prevent the health status of the workers;

Nutritional deficit and sexual issues are ranked high in the health and psychological issues faced by the tobacco workers in the study area.

\section{CONCLUSION}

Tobacco is the one of the major form of pleasure to the many of the modern people. They were use the cigarette as a pleasure device or to show their stylish identity to others. Malawian tobacco is the one of the finest and quality tobacco used in the most of the world leading cigarette manufacturers for its rich taste. This study aimed to understand the socio-economic; health and psychological issues faced by the tobacco workers in Mangochi district of Malawi. It found that many of the tobacco farming workers were dissatisfied with the job and they were getting paid less compared to the global standards. They were living in the poor conditions especially they were made the houses by hard boards and also using some long grasses found near the lake. Their health condition is too poor due to onetime food and that also Mbatata which not able to fulfill the nutrition requirement of the agriculture workers. Even they are not having the smoking habits due to handling and processing of tobacco leaves they are having the huge chance of getting tuberculosis disease. This study suggested that more awareness should be created among the tobacco farming workers about the nutritional food and health prevention by both government and non government parties. It concludes that minimum wages of the farming workers suppose to be revised according to the global standards to provide the better salary to the people and prevent them with good mental and physical health. Further, this study opens up the

Blue Eyes Intelligence Engineering

\& Sciences Publication 
new avenues for the researchers to conduct more empirical and health related studies on this phenomena to picture out the reality or pain of the tobacco workers to the people getting pleasure by smoking.

\section{REFERENCES}

1. Alphonse .M and Upadhaya.M.,(1988), "SocioEconomic survey of families in Trank Bund Road slum", Loyola Institute of Development Services, Madras, 1988.

2. Gracious Thomas,(1992), "Status of Female Domestic workers", social welfare, Vol XXXIX, No.2 May, pp. 1314.

3. http://www.tobaccoinduceddiseases.org/Humantrafficking-and-forced-labour-in-Malawi-s-tobaccogrowing-sector, $84669,0,2 . \mathrm{html}$

4. http://www.wadonda.com/Chirwa_2011_tobacco.pdf

5. https://www.theguardian.com/globaldevelopment/2011/sep/14/malawi-child-labour-tobaccoindustry

6. Nayak,V.T.,(1984) "Women Domestic workers in South India". Social Action Delhi, VP.34, No.4.

7. James, F.A., Vettriselvan, R., Srinivasan, R., Poongavanam, S., Rengamani, J. Problems of women domestic workers in Tamil Nadu, International Journal of Engineering and Advanced Technology, 2019:8(2S2): 391-395.

8. Jivita, S., \&Poongavanam, S. Risk-taking proficiencies of female occupation persons following occupational evolution. Medico-Legal Update, (2018);18(1): 435-438.

9. Rengamani, J. Impact of occupational stress on the job satisfaction of civil engineers in the construction companies in chennai. International Journal of Civil Engineering and Technology, (2018);9(8):542-550.

10. Thiruvasasagam G., Rajasekar D., \&Vettriselvan R. Profile and Problems of Women Domestic Workers in Mangochi, Malawi, International Journal of Recent Technology and Engineering, 2019: 8(2s3):1167-1171

11. Vettriselvan R. Ruben Anto. JesuRajan FSA. Pathetic Health Status and Working Condition of Zambian Women, Indian Journal of Public Health Research \& Development, 2018;9(9):259-264.

12. Vettriselvan, R., Rengamani, J., James, F.A., Srinivasan, R., Poongavanam, S. Issues and challenges of women employees in Indian technical industries International Journal of Engineering and Advanced Technology, 2019: 8(2S2): 404-409.

\section{AUTHORS PROFILE}

Col.Dr.G.Thiruvasagam brings with him his dynamic experience of four and half decades, his keen sense of justice and his generous spirit of fraternity all of which served him well in a career spanning 44 years as Professor of Commerce and Management, Principal and Member of the Syndicate of Madurai Kamaraj University. Nominated as Vice Chancellor of two eminent universities in Tamil Nadu namely Bharathiar University, Coimbatore and University of Madras. Presently, serving as the ViceChancellor of Academy of Maritime Education and Training (AMET) deemed to be University, Chennai, since 2012. He has authored 12 textbooks and around 51 publications published in National and International Journals. He is serving as a Member in various committees like Planning and Academic Committees, UGC, NAAC and Tamil Nadu State Council for Higher Education. He was invited to serve on the Central Advisory Board of Education (CABE), for making recommendations to the MHRD on all aspects of Higher Education. That $60 \mathrm{MoUs}$ have been signed with major industries and leading universities of the world. He had held several notable positions and received awards including the National Award for Social Service from the then President of India, Dr.A.P.J. Abdul Kalam.

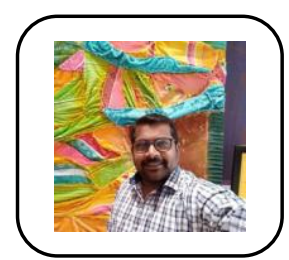

Dr. D. Rajasekar, Professor at AMET Business School, AMET deemed to be University has 4 years of industrial experience and 15 years of teaching experience. He has presented more than 60 Papers in National and International conferences and has published around 100 Papers in International Journals and also published 21 textbooks. He is a Gold medalist in MBA ( Finance and Marketing) from Tamilnadu Open University and received the same from Hon'ble Ex-Tamil nadu, Governor Shri. Surjit Singh Barnala. He is a rank holder at Madras University. He has received the awards "Outstanding Scientist in Commerce", "Best Faculty Award", "Best Research Advisor Award" "Highest Book Publication Award" and Dr.Radhakrishnan Gold Medal Award in the year 2017.

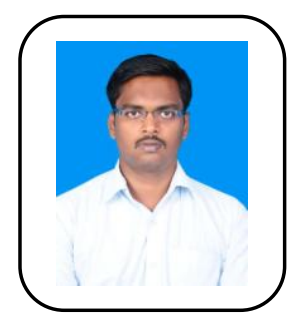

Dr.R.Vettriselvan, working as a Senior Lecturer in School of Management and Commerce, DMI-St. John the Baptist University, Mangochi, Malawi. Formerly Assistant Professor in AMET Busines School, Academy of Maritime Education and Training (AMET) Deemed to be University and acted as a Head of the Department, School of Commerce and Management Studies, DMISt. Eugene University, Zambia. He published 5 books and more than 50 research articles in SCOPUS/UGC/Referred international/ national journals and Conference volumes. He received travel grant award to USA from Population Association of America, Doctoral Fellowship from ICSSR, New Delhi. He got received best paper, best paper presenter, Best Young Faculty 2018, Bright Educator 2018 and Best Academician of the year (Male) 2018 He presented more than 50 research article in the National and International Conferences conducted in India, Zambia, Malawi and USA. 